\title{
Effects of reduced height (Rht) and photoperiod insensitivity (Ppd) alleles on yield of wheat in contrasting production systems
}

Article

Accepted Version

Addisu, M., Snape, J.W., Simmonds, J. R. and Gooding, M.J. (2010) Effects of reduced height (Rht) and photoperiod insensitivity (Ppd) alleles on yield of wheat in contrasting production systems. Euphytica, 172 (2). pp. 169-181. ISSN 0014-2336 doi: https://doi.org/10.1007/s10681-009-0025-2 Available at https://centaur.reading.ac.uk/16131/

It is advisable to refer to the publisher's version if you intend to cite from the work. See Guidance on citing.

Published version at: http://www.springerlink.com/content/w760541776105q82/

To link to this article DOI: http://dx.doi.org/10.1007/s10681-009-0025-2

Publisher: Springer

Publisher statement: The original publication is available at www.springerlink.com

All outputs in CentAUR are protected by Intellectual Property Rights law, including copyright law. Copyright and IPR is retained by the creators or other copyright holders. Terms and conditions for use of this material are defined in the End User Agreement. 


\section{CentAUR}

Central Archive at the University of Reading

Reading's research outputs online 


\title{
Effects of reduced height (Rht) and photoperiod insensitivity (Ppd) alleles on yield of wheat in contrasting production systems
}

\author{
M. Addisu • J. W. Snape • J. R. Simmonds • M. J. Gooding
}

M. Addisu

Crops Research Unit, Department of Agriculture, The University of Reading, Earley Gate, P.O. Box 237, Reading, RG6 6AR, UK

J. W. Snape

Crop Genetics Department, John Innes Centre, Colney Lane, Norwich, NR4 7UH, Norfolk UK

J. R. Simmonds

Crop Genetics Department, John Innes Centre, Colney Lane, Norwich, NR4 7UH, Norfolk UK

M. J. Gooding (for correspondence)

Crops Research Unit, Department of Agriculture, The University of Reading, Earley Gate, P.O. Box 237, Reading, RG6 6AR, UK

e-mail: m.j.gooding@reading.ac.uk 


\begin{abstract}
Near isogenic lines (NILs) varying for reduced height (Rht) and photoperiod insensitivity (Ppd-D1) alleles in a cv. Mercia background (rht (tall), Rht-B1b, Rht-D1b, Rht-B1c, $R h t 8 c+P p d-D 1 a, R h t-D 1 c, R h t 12)$ were compared for interception of photosynthetically active radiation (PAR), radiation use efficiency (RUE), above-ground biomass (AGB), harvest index (HI), height, weed prevalence, lodging and grain yield, at one field site but within contrasting ('organic' v 'conventional') rotational and agronomic contexts, in each of three years. In the final year, further NILs (rht (tall), Rht-B1b, Rht-D1b, Rht-B1c, Rht-B1b+Rht-D1b, Rht-D1b+Rht-B1c) in Maris Huntsman and Maris Widgeon backgrounds were added together with 64 lines of a doubled haploid (DH) population [Savannah $($ Rht-D1b) $\times$ Renesansa $(R h t-8 c+P p d-D 1 a)]$. There
\end{abstract} were highly significant genotype $\times$ system interactions for grain yield, mostly because differences were greater in the conventional system than in the organic system. Quadratic fits of NIL grain yield against height were appropriate for both systems when all NILs and years were included. Extreme dwarfing was associated with reduced PAR, RUE, AGB, HI, and increased weed prevalence. Intermediate dwarfing was often associated with improved $\mathrm{HI}$ in the conventional system, but not in the organic system. Heights in excess of the optimum for yield were associated particularly with reduced $\mathrm{HI}$ and, in the conventional system, lodging. There was no statistical evidence that optimum height for grain yield varied with system although fits peaked at $85 \mathrm{~cm}$ and $96 \mathrm{~cm}$ in the conventional and organic systems, respectively. Amongst the DH lines, the marker for Ppd-D1a was associated with earlier flowering, and just in the conventional system also with reduced PAR, AGB and grain yield. The marker for Rht-D1b was associated with reduced height, and again just in the conventional system, with increased $\mathrm{HI}$ and grain yield. The marker for Rht8c reduced height, and in the conventional system only, increased HI. When using the System $\times$ DH line means as observations grain yield was associated with 
height and early vegetative growth in the organic system, but not in the conventional system. In the conventional system, PAR interception after anthesis correlated with yield. Savannah was the highest yielding line in the conventional system, producing significantly more grain than several lines that out yielded it in the organic system.

Keywords $R h t 1 \cdot R h t 2 \cdot R h t 3 \bullet R h t 8 \cdot R h t 10 \bullet R h t 12 \cdot P p d-D 1 a \bullet$ organic agriculture $\bullet$ radiation use efficiency $\bullet$ harvest index $\bullet$ yield components

\begin{tabular}{ll}
\multicolumn{2}{l}{ Abbreviations } \\
AGB & Above ground biomass \\
DH & Doubled Haploid \\
DM & Dry matter \\
FR:R & Far Red: Red reflectance ratio \\
GS & Growth Stage \\
N & Nitrogen \\
NIL & Near Isogenic Line \\
PAR & Photosynthetically Active Radiation \\
REML & Residual Maximum Likelihood \\
RUE & Radiation use efficiency
\end{tabular}




\section{Introduction}

Flintham et al. (1997) related the effects of alleles conferring insensitivity to gibberellic acid (GA) on wheat yield to their stem shortening ability. For example, grain yields at excessive crop heights can be reduced because of poor harvest indices (Flintham et al. 1997) and/or increased lodging (Berry et al. 2004). Conversely, poor yields associated with severe dwarfism have been ascribed to poorer biomass accumulation; a consequence of reduced light interception and/or reduced radiation use efficiency (Austin 1999). Flintham et al. (1997) identified a target height range for maximising yield, and demonstrated that effects of reduced height alleles (Rht) on grain yield of near isogenic lines (NILs) depended on the stature of their tall (rht) backgounds at particular locations. Thus, the 'Green Revolution' genes, Rht-B1b and Rht-D1b, were most beneficial in comparatively tall backgrounds, and in environments conducive to tall stature (Richards 1992; Flintham et al. 1997; Chapman et al. 2007).

The plots studied by Flintham et al. (1997) received fertilizer and fungicide programmes according to local commercial practice. There is uncertainty as to whether dwarfing genes are as relevant to other production methods, such as in organic systems, where the use of synthetic inputs is curtailed or reduced. Frequent nitrogen deficiency in such systems (Berry et al. 2002) could reduce the risk of lodging, and hence one of the penalties of height. Shortening with dwarfing genes can favour certain diseases (Simon et al. 2004; Srinivasachary et al. 2008), and reduce competitive ability or tolerance against weeds (Zerner et al. 2008), that might otherwise be controlled with agrochemicals in intensive systems (Austin 1999). Early crop vigour has been idenitfied as particularly useful in organic contexts (Wolfe et al. 2008) and we have already shown that several dwarfing genes can reduce early season growth in such systems (Addisu et al. 
2009). Nonetheless, Cosser et al. (1997) did find that near isogenic lines containing Rht-B1b and/or Rht-D1b increased harvest index and grain yield in an organic system, when compared with a particularly tall background in one season.

Here we describe experiments that used both near-isogenic lines and a doubled haploid population, to determine whether the optimum height of a wheat crop varied between two contrasting production systems (intensive 'conventional' v. 'organic') on a single site. To investigate the yield response surface to height we included GA-insensitive alleles conferring both semi- (Rht-B1b, Rht-D1b), and severe dwarfism (Rht-B1c, Rht-D1c) in backgrounds that vary in stature. We also included alleles conferring semi- (Rht8c, Ppd-D1a; Worland et al. (1998)) and severe (Rht12; Worland et al. (1994)) dwarfism without greatly affecting GAsensitivity. Ppd-D1a reduces height through conferring photoperiod insensitivity and hence time to jointing in short days. This more rapid development has already been associated with improved early season resource capture, and hence potential benefits for use in organic agriculture (Addisu et al. 2009).

\section{Materials and methods}

Field experiments were conducted on a free-draining sandy loam overlying coarse red-brown sand of the Sonning series (Jarvis 1968), in each of three growing seasons (2005/06, 2006/07 and 2007/08) at the Crops Research Unit, Sonning, University of Reading, UK ( $\left.51^{\circ} 29^{\prime} \mathrm{N}, 0^{\circ} 56^{\prime} \mathrm{W}\right)$. Weather data (Table 1) were recorded at an automated weather station at the site. Land had been managed conventionally with robust programmes of synthetic fertilizer and agrochemicals (Table 2), or organically since 2001. Untreated seeds were drilled at a nominal depth of 50mm, 
on $120 \mathrm{~mm}$ rows in $2 \mathrm{~m}$ wide plots separated by $0.5 \mathrm{~m}$ double-width track wheelings. A plan and rotational history of the site, together with more detailed descriptions of establishment methods, cultivars, markers and seed quality is given in Addisu et al. (2009).

In each of the three years seven near isogenic lines (NILs) with a cv. Mercia background (rht (tall), Rht-B1b, Rht-D1b, Rht-B1c, Rht8c+Ppd-D1a, Rht-D1c, Rht12) were sown in 10m (2005 and 2006) and 7.5m (2007) long plots, randomized in four $(2005,2006)$ or three (2007) blocks, on both the organic and conventional areas on the same date, at $300 \mathrm{seeds} / \mathrm{m}^{2}$ (2005 and 2006), and 250 seeds $/ \mathrm{m}^{2}$ (2007). In the final year, further NILs (rht (tall), Rht-B1b, Rht-D1b, Rht-B1c, Rht-B1b+Rht-D1b, Rht-D1b+Rht-B1c) in both Maris Huntsman and Maris Widgeon backgrounds were added.

In 2007, a further experiment involved sixty-two lines, varying in height, selected from a recombinant doubled haploid (DH) population of Savannah $\times$ Renesansa. Savannah carried the Rht1-D1b allele while Renesansa carried Rht8c and Ppd-D1a but not Rht1-D1b. Together with the parents the 64 lines were sown in an $8 \times 8$ row + column design for two replicates on both the conventional ( $7.5 \mathrm{~m}$ plots) and organic areas $\left(5 \mathrm{~m}\right.$ plots) at $300 \mathrm{seeds} / \mathrm{m}^{2}$.

Assessments

Throughout growth in the conventional plots, the proportionate interception of photosynthetically active radiation (PAR) was derived from ceptometer (AccuPAR LP-80; Decagon Devices Inc, Pullman, Washington) readings above and beneath (10 $\mathrm{mm}$ above soil level) the canopy (Addisu et al. 2009). This data set was combined with that for daily radiation receipts, to derive total PAR interception over the life of the crop (Kindred and Gooding 2005). 
To determine the end of canopy photosynthetic function, the red $(660 \mathrm{~nm})$ : far red $(730 \mathrm{~nm})$ reflectance ratio was recorded with sensors (SKR 1800, Skye Instruments Ltd, Llandrindod Wells, UK) above the canopy from anthesis onwards. The ratio achieved above the canopy was expressed as a percentage of that recorded for bare ground at the same time. 'Green cover' was determined by first subtracting this percentage from 100, and then for each plot expressing green cover as a percentage of the maximum for the particular plot from anthesis onwards. This final step was necessary to account for differences between genotypes in colour and ground cover, unrelated to degree of senescence. The reduction in 'green cover' over time was fitted with a modified gompertz curve (Gooding et al. 2000), and the end of canopy photosynthetic function taken as when green cover was at $80 \%$ of maximum, i.e. at the onset of the rapid phase of senescence.

Time to anthesis (GS 65) was derived visually from daily plot inspections in both conventional and organic plots. Crop height was assessed with a rising disc of polystyrene (Addisu et al. 2009). Final crop height was calculated as the mean of three assessments taken after anthesis. Lodging was assessed by accounting for both angle of lean and proportion of plot affected (Caldicott and Nuttall 1979). In the organic areas, weed biomass was determined by destructively sampling $0.5 \mathrm{~m}^{2}$ at anthesis, and again at maturity. Harvest index was derived from destructive sampling and partitioning (Kindred and Gooding 2005) before harvesting grain from the central $1.3 \mathrm{~m}$ of each plot with a plot combine.

Statistical analysis 
The performance of NILs within each year and system were subjected to six $(3$ years $\times 2$ systems) separate analyses of variance. To combine the data over years to assess the significance of system and system.genotype, the unbalanced structure was dealt with by using Residual Maximum Likelihood (REML) analysis in Genstat 10, where the fixed model was system + genotype + system.genotype, and the random model was year/system/block/genotype. To investigate relationships with height between the system $\times$ dwarfing gene means, quadratic regression was employed with system as a grouping factor. To investigate relationships over different cultivar backgrounds, main effects of background within a system were removed from the yield (but not height) variables by subtracting constant effects from that of Maris Huntsman. For the doubled haploid lines REML analysis was conducted using presence and absence of markers for Rht-D1b, Rht8c and Ppd-D1a, as fixed effects. The random model was block/(row+column) when restricted to a production system, or otherwise system/block/(row+column).

\section{Results}

The 2005/6 season was drier than the long term average (Table 1). Not withstanding a wet May, grain filling in June and July was associated with comparatively dry and hot conditions, and hence the earliest harvest (Table 2). The 2006/7 season was relatively wet throughout, except for an exceptionally dry April. This dry spell coincided with large nitrogen top-dressings (Table 2) and lack of rain may have contributed to very poor nitrogen uptake efficiencies in the conventional area (Addisu 2009). The period of rapid canopy formation and grain filling (March 
to July) was comparatively wet in 2007/08, and further rain in August contributed to delayed harvest (Table 1).

Near isogenic lines

The Mercia NIL with Rht8c+Ppd-D1a always flowered in the last week of May. Averaged over season and system, rht(tall), Rht-B1b and Rht-D1b all flowered 9 days after $R h t 8 c+P p d-D 1 a$ $(\mathrm{SED}=0.22,98 d f)$. The severe dwarfing alleles or combinations conferred further delays in flowering (13, 15, 18, 15 and 15 after Rht8c+Ppd-D1a for Rht-B1c, Rht-D1c, Rht12, Rht$B 1 b+R h t-D 1 b, R h t-D 1 b+R h t-B 1 c$, respectively). There was no evidence of a System.Dwarfing gene interaction on flowering time.

The yields of wheat varied with season; comparatively high yields achieved in 2008 contrasted with low yields in 2007 (Fig. 1). For grain yield and height at maturity the effects of Background, Dwarfing gene, System.Background, System.Dwarfing gene, and Background.Dwarfing gene were all significant at the $P \leq 0.001$ level.

\section{Mercia}

None of the Mercia lines grew taller than $90 \mathrm{~cm}$. Crop heights were significantly reduced by the semi-dwarfing alleles (Rht-B1b, Rht-D1b, Rht8c+Ppd-D1a) by 10 to $15 \%$ (Fig. 1). Rht-Blc conferred dwarfing intermediate to the semi-dwarfing alleles and the very severe $(R h t-D 1 c$, Rht12) alleles. However, there was no evidence that adding a major gene for reduced height to the commercially-released cultivar increased yield in either system (Fig. 1a-c). Yield differences among Mercia NILs were greater in the conventional system than in the organic system in 2007 
and 2008 (Fig. 1b,c). Changes in relative yields of specific alleles between the two systems also contributed to the System.Dwarfing gene interaction. Firstly, Rht-B1c performed relatively better in the conventional system than in the organic system, causing the relationship between height and yield to deviate significantly from linearity in 2006 and 2008 (Fig. 1a,c), but only in the conventional system. Secondly, yield of Rht8c+Ppd-D1a was significantly less than $r h t($ tall $)$ and the other semi-dwarf NILs in just the conventional system in 2007 (Fig. 1b), when it was also associated with poor RUE (Table 3).

Although semi-dwarfing alleles failed to increase the yield of Mercia, they did tend to increase harvest index, significantly so in the conventional system of 2006 (Table 4). Where improvements in harvest index did occur, however, they were countered by reductions in above ground biomass. Similarly, Rht-B1c in Mercia achieved either greater or comparable harvest indices to that of $\operatorname{rht}($ tall) and semi-dwarfs in the conventional system in all years, but reduced above-ground biomass as a result of both reduced PAR interception (in 2005/6 and 2006/7) and RUE (in 2006/7 and 2007/8) (Table 3). In the organic system, Rht-B1c was associated with significantly reduced harvest index (Table 4). This contrasting effect of Rht-B1c on harvest index contributed to a significant $(P=0.013)$ System.Dwarfing gene interaction. A similar interaction was evident for Rht-D1c in 2006, although in subsequent years, and for Rht12 in all years, severe dwarfism was associated with reduced harvest index in both systems. These two shortest Mercia NILS (Rht-D1c, Rht12) were associated with the lowest biomass, PAR interception and RUE in both systems in all years (Tables 3 and 4).

Maris Huntsman and Maris Widgeon 
In contrast to Mercia, the heights of Maris Huntsman and Maris Widgeon exceeded 100cm (Fig. $1 d, e)$. In the conventional system this was associated with significant lodging by anthesis $(21 \%$ and 6\% for Maris Huntsman and Maris Widgeon, respectively). For both cultivars, lodging was controlled, and yield and harvest index increased by the addition of either of the Norin-10 semidwarfing alleles (Rht-B1b and Rht-D1b) (Fig. 1d,e). In the organic system, differences in yield amongst these NILs were much less, although Rht-B1b or Rht-D1b still appeared to increase yield (but $P>0.05$ ). Further dwarfism in Maris Huntsman, either by combining Rht-B1b with $R h t-D 1 b$ or by using Rht-B1c was associated with increased harvest index in the conventional system but the opposite effect in the organic system (Table 5), giving a similar System.Dwarfing gene interaction to that seen with Rht-B1c in Mercia. Also consistent with Merica, the severest dwarfism, achieved here by combining Rht-D1b with Rht-B1c was associated with reduced harvest index, above ground biomass and radiation use efficiency in both systems and backgrounds (Tables 3 and 5).

\section{Analysis combined over backgrounds}

In the regression of REML predicted means for yield against height (Fig. 2), there was a very highly significant $(P<0.001)$ change to the model when both linear and quadratic terms were allowed to vary with System (Fig. $2, r^{2}$ adj. $=0.91$ ). As previously described, the interactions with System arose mostly because the effects of height and Dwarfing gene on yield were greater in the higher yielding conditions of the conventional system. When the effects of yield potential of the system were removed, i.e. by expressing yields as a percentage of the maximum predicted by the quadratic fits $(6.02 \mathrm{t} \mathrm{DM} / \mathrm{ha}$ at $85 \mathrm{~cm}$ for conventional, and $3.52 \mathrm{t} \mathrm{DM} / \mathrm{ha}$ at $96 \mathrm{~cm}$ for organic), there was no statistical justification for fitting separate quadratic responses of yield 
against height for the two systems ( $P=0.123$ for the change). In this latter analysis: the common line estimates for constant, linear and quadratic effects were -105 $(\mathrm{SE}=15.1), 4.53(\mathrm{SE}=0.451)$, and $-0.025(\mathrm{SE}=0.00312)$, respectively; the variance accounted for among the 38 genotype $\times$ system means was $87 \%\left(r_{a d j}^{2}\right)$; and the height at fitted maximum yield was $91 \mathrm{~cm}$.

There was no evidence that the mode of action of the dwarfing gene influenced the relationship between height and yield. The alleles producing the shortest plants produced similarly poor yields irrespective of whether the allele conferred GA insensitivity (Rht-D1c) or not (Rht12). The additive effects of Rht8c+Ppd-D1a (GA-sensitive) in Mercia produced plants of similar stature and yield to Rht-D1b (GA-insensitive).

Despite the similarities in optimum height for yields in the two systems, there were factors that might have been expected to contribute to more of an interaction. As well as lodging only occurring in the conventional system, weeds were mostly found in the organic system, where they proliferated in plots of the severe dwarf genotypes (Fig. 3), accumulating $5 \mathrm{t} \mathrm{DM} / \mathrm{ha}$ in Rht12.

Performance of doubled haploid lines

The REML analysis including the allele specific markers for Ppd-D1a, Rht-D1b and Rht8c as fixed effects revealed significant associations (Table 6). Ppd-D1a was associated with reduced time to flowering of 7 days $(\mathrm{SED}=0.68 ; d f>200)$ irrespective of system. In the conventional system Ppd-D1a was associated with reduced interception of PAR, above-ground biomass and reduced grain yield. In the organic system, the reverse effects of Ppd-D1a biomass and grain yield were apparent. The marker for Rht-D1b was associated with a slight delay in flowering (2 
days; $\mathrm{SED}=0.56$ ) and a reduction in height, irrespective of system (Table 6). In the conventional system, Rht-D1b was associated with increased grain yield through improved harvest indices, rather than increased above ground biomass. Rht-D1b was not associated with increased harvest index, or grain yield in the organic system. The marker for Rht8c was associated with slightly earlier flowering ( 2 days; $\mathrm{SED}=067$ ) and reduced height irrespective of system. In the conventional system Rht8c was associated with increased harvest index but reduced biomass production. Grain yield appeared unaffected by Rht8c in either system.

In the analysis using individual DH lines as fixed effects, there were very highly significant $(P<0.001)$ effects of line on final crop height, grain yield, harvest index, and above-ground crop biomass (Fig. 4) in both systems. Significant cross-overs in performance of lines in the two systems were evident. The highest yielding line in the conventional area was Savannah (Fig. 4), but this was far from the case in the organic area.

Associations between height and grain yield were much weaker in the DH population than they were amongst the NILs. The range of heights was slightly less than in the NIL comparisons, but many more factors were contributing to the variation in yield. For grain yield there was statistical justification for allowing the quadratic response to height to vary with system $(P=0.05)$, but this was mostly due the response in the organic area (Fig. $4 a)$. In the conventional area there was no association between height and grain yield, any such relationship possibly being masked by other confounding influences such as date of flowering and senescence. For instance, in the conventional area, grain yield was significantly associated with post-anthesis PAR interception (correlation coefficient $(r)=0.57$; d.f. $=62 ; P<0.001$ ). In addition to height, the yield of the DH lines in the organic area was significantly associated with assessments of establishment and early growth that were associated with the presence of Ppd-D1a (Addisu et al. 
2009). For example, there was a significant correlation $(r=0.58 ; d f=62 ; P<0.001)$ between grain yield and a score associated with plant population, and early ground cover, dry matter accumulation, and above ground nitrogen (PC1 in Addisu et al. 2009). There was no such correlation between early growth and yield in the conventional area $(r=0.02 ; P=0.88)$.

For harvest index, the fitted quadratic response to height was the same in each system, declining as heights exceeded $80 \mathrm{~cm}$ (Fig. $4 b$ ). Above ground biomass increased with height in both systems, more so in the organic system than in the conventional system. In neither system was there any evidence that this response deviated from linearity over the ranges observed (Fig. $4 c)$.

\section{Discussion}

The fitted peak yields in the NIL experiment of 7 and $4 \mathrm{t} / \mathrm{ha}$ at $15 \%$ moisture for conventional and organic systems, respectively, are not unrepresentative of UK yields, especially considering that the regression constants for the different backgrounds were rebased to that of Maris Huntsman.

Despite including a wider range of gibberellin insenstive dwarfing alleles than Flintham et al. (1997), and the inclusion of two gibberellin sensitive dwarfing alleles, our results are consistent in showing optimal heights for grain yield in conventional production systems in NW Europe is broadly between 80 and $100 \mathrm{~cm}$. We demonstrate and confirm that excessive dwarfism for yield can be associated with reduced PAR, RUE, AGB, HI, and in the organic system with increased weed prevalence (Flintham et al. 1997; Cosser et al. 1997; Austin 1999). Excessive height for yield can be particularly associated with reduced HI (Flintham et al. 1997) and, in conventional 
systems, lodging (Berry et al. 2004). Our results are also consistent with others in showing that the value of semi-dwarfing genes is greater in taller backgrounds (Richards 1992; Flintham et al. 1997).

Taken together with the DH results, there is a suggestion that the ideal height for a wheat crop could be slightly higher in an organic system than in a conventional system, but this can not be supported statistically. We could not reproduce the statistical yield benefit of adding Rht-B1b or Rht-D1b to Maris Widgeon grown organically reported by Cosser et al. (1997), possibly because of the greater weed pressures found in the present study. Similar to Cosser et al. (1997), however, we have no evidence that use or otherwise of major semi-dwarfing genes to aid performance in conventional systems would be detrimental to grain yield if the same selections were grown in an organic system. This conclusion is reached despite influences that might have been expected to lead to more of a distinction in target heights between the two systems: high weed pressures in the organic system, and significant lodging in the conventional system. We also find that benefits of intermediate dwarfism for improved harvest index in the conventional system are not reliably expressed in the organic system. It is possible that competition from weeds and/or reduced late-season nutrient availability (Wolfe et al. 2008; Baresel et al. 2008) could reduce grain numbers and/or mean grain weight and hence reduce efficiency of dry matter partitioning to the grain in the organic system.

Although we do not report crossovers in performance based on Rht inclusion, the DH experiment demonstrates that crossovers do occur. It seems that the presence or absence of PpdD1 a can contribute to these crossovers. The relationship between the duration of canopy life, hence light interception post-anthesis, and grain yield is well known (Verma et al. 1994). The negative association between the marker for Ppd-D1a on time to senescence, AGB and grain 
yield in the conventional system is consistent with this relationship. Similarly, the earlier maturation of Rht8c+Ppd-D1a in Mercia may have contributed to the reduced yield seen for this line in the conventional system of 2007. Foulkes et al. (2004), also found Ppd-D1a to reduce AGB in the UK. In the organic system, however, Ppd-D1a appeared to increase yields, possibly associated with increased early resource capture. The positive associations between Ppd-D1a, early season growth, and grain yield in the organic system is consistent with the view that early vigour is particularly important in this context (Wolfe et al. 2008), i.e. in situations where resources such as nitrogen are likely to be initially plentiful after a legume-rich ley, but then become deficient later in the season (Baresel et al. 2008; Addisu 2009).

\section{Acknowledgments}

The authors are grateful to the Felix Trust for providing a scholarship for M. Addisu, RJ Casebow and RE Kiff for technical support, and to Dr HE Jones for useful comments made on this manuscript.

\section{References}

Addisu M (2009) Effects of Green Revolution and other dwarfing genes in contrasting wheat production systems. $\mathrm{PhD}$ thesis. The University of Reading

Addisu M, Snape JW, Simmonds JR, Gooding MJ (2009) Reduced height (Rht) and photoperiod insensitivity (Ppd) allele associations with establishment and early growth of wheat in contrasting production systems. Euphytica 166:249-267

Austin RB (1999) Yield of wheat in the United Kingdom: Recent advances and prospects.

Crop Sci 39:1604-1610

Baresel, Zimmermann G, Reents HJ (2008) Effects of genotype and environment on N uptake and $\mathrm{N}$ partition in organically grown winter wheat (Triticum aestivum L.) in Germany. Euphytica 163:347-345

Berry PM, Sylvester-Bradley R, Philipps L (2002) Is the productivity of organic farms restricted by supply of available nitrogen? Soil Use Manage 18:248-255

Berry PM, Sterling M, Spink JH, Baker CJ, Sylvester-Bradley R, Mooney SJ, Tams AR, Ennos AR (2004) Understanding and reducing lodging in cereals. Adv Agron 84:217-271 
Caldicott JJB, Nuttal AM (1979) A method for the assessment of lodging in cereal crops. J Nat Inst Agric Bot 15:88-91

Chapman SC, Mathews KL, Trethowan RM, Singh RP (2007) Relationships between height and yield in near-isogenic spring wheats that contrast for major reduced height genes. Euphytica 157:391-397

Cosser ND, Gooding MJ, Davies WP, Thompson AJ, Froud-Williams RJ (1997) Cultivar and Rht gene influences on the competitive ability, yield and the breadmaking quality of organically grown winter wheat. In: Gooding MJ, Shewry PR (eds) Aspects of Applied Biology 50. Optimising Cereal Inputs: Its Scientific Basis. Association of Applied Biologists, Warwick, pp 39-51

Gooding MJ, Dimmock JPRE, France J, Jones SA (2000) Green leaf area decline of wheat flag leaves: the influence of fungicides and relationships with mean grain weight and grain yield. Ann Appl Biol 136:77-84

Flintham JE, Borner A, Worland AJ, Gale MD (1997) Optimizing wheat grain yield: Effects of Rht (gibberellin-insensitive) dwarfing genes. J Agric Sci 128:11-25

Foulkes MJ, Sylvester-Bradley R, Worland AJ, Snape JW (2004) Effects of a photoperiodresponse gene Ppd-D1 on yield potential and drought resistance in UK winter wheat. Euphytica 135:63-73

Jarvis RA (1968) Soils of the Reading district. Rothamsted Experimental Station, Harpenden, UK

Kindred DR, Gooding MJ (2005) Heterosis for yield and its physiological determinants in wheat. Euphytica 142:149-159

Richards RA (1992) The effect of dwarfing genes in spring wheat in dry environments. 1. Agronomic characteristics. Aust J Agric Res 43:517-527

Simon MR, Worland AJ, Struik PC (2004) Influence of plant height and heading date on the expression of the resistance to Septoria tritici blotch in near isogenic lines of wheat. Crop Sci 44:2078-2085

Srinivasachary, Gosman N, Steed A, Simmonds J, Leverington-Waite M, Wang Y, Snape J, Nicholson P (2008) Susceptibility to Fusarium head blight is associated with the Rht-D1b semi-dwarfing allele in wheat. Theor Appl Genet 116:1145-1153

Verma V, Foulkes MJ, Worland AJ, Sylvester-Bradley R, Caligari PDS, Snape JW (2004) Mapping quantitative trait loci for flag leaf senescence as a yield determinant in winter wheat under optimal and drought-stressed environments. Euphytica 135:255-263.

Wolfe MS, Baresel JP, Desclaux D, Goldringer I, Hoad S, Kovacs G, Loschenberger F, Miedaner T, Ostergard H, van Bueren ETL (2008) Developments in breeding cereals for organic agriculture. Euphytica 163:323-346

Worland AJ, Sayers EJ, Borner A (1994) The genetics and breeding potential of Rht12, a dominant dwarfing gene in wheat. Plant Breed 113:187-196

Worland AJ, Korzun V, Roder MS, Ganal MW, Law CN (1998) Genetic analysis of the dwarfing gene Rht8 in wheat. Part II. The distribution and adaptive significance of allelic variants at the Rht8 locus of wheat as revealed by microsatellite screening. Theor Appl Genet 96:1110-1120

Zerner MC, Gill GS, Vandeleur RK (2008) Effect of height on the competitive ability of wheat with oats. Agron J 100:1729-1734

Zadoks JC, Chang TT, Konzak CF (1974) A decimal code for the growth stages of cereals. Weed Res 44:415-421 

Table 1 Monthly weather data and 45 year means at the experimental site

\begin{tabular}{lccccccccc}
\hline \multirow{2}{*}{ Months } & \multicolumn{3}{l}{ Rainfall $(\mathrm{mm})$} & & \multicolumn{3}{l}{ Mean temperature $\left({ }^{\circ} \mathrm{C}\right)$} \\
\cline { 2 - 3 } \cline { 8 - 10 } & $2005 / 6$ & $2006 / 7$ & $2007 / 8$ & Mean & & $2005 / 6$ & $2006 / 7$ & $2007 / 8$ & Mean \\
\hline September & 37.4 & 50.4 & 40.1 & 57.4 & & 15.4 & 17.3 & 14.5 & 14.1 \\
October & 56.0 & 123.6 & 35.1 & 66.3 & & 13.4 & 13.2 & 11.2 & 10.7 \\
November & 31.9 & 107.4 & 68.8 & 63.6 & & 5.9 & 7.9 & 7.7 & 7.1 \\
December & 52.0 & 82.6 & 45.6 & 63.7 & & 4.0 & 6.7 & 5.4 & 5.1 \\
January & 13.9 & 65.8 & 86.4 & 59.3 & & 4.4 & 7.1 & 6.4 & 4.3 \\
February & 47.2 & 82.8 & 19.6 & 39.9 & & 3.9 & 6.1 & 5.4 & 4.5 \\
March & 45.6 & 44.4 & 82.6 & 48.0 & & 5.3 & 7.1 & 6.5 & 6.5 \\
April & 25.7 & 1.8 & 59.0 & 49.5 & & 9.1 & 11.4 & 8.1 & 8.6 \\
May & 79.7 & 92.2 & 66.4 & 49.1 & & 12.6 & 12.4 & 13.7 & 12.0 \\
June & 11.1 & 93.7 & 49.4 & 49.0 & & 16.4 & 16.1 & 14.9 & 15.0 \\
July & 32.0 & 115.6 & 77.6 & 45.0 & & 20.6 & 16.3 & 16.5 & 17.2 \\
August & 36.2 & 40.5 & 74.6 & 57.6 & & 16.8 & 16.3 & 16.8 & 17.0 \\
\hline
\end{tabular}


Table 2 Husbandry applied to the conventional experiments

\begin{tabular}{|c|c|c|c|c|c|}
\hline \multirow[t]{2}{*}{ Treatment } & \multirow[t]{2}{*}{$\begin{array}{l}\text { GS (Zadoks } \\
\text { et al. 1974) }\end{array}$} & \multirow[t]{2}{*}{$2005 / 2006$} & \multirow[t]{2}{*}{$2006 / 2007$} & \multicolumn{2}{|c|}{$2007 / 2008$} \\
\hline & & & & Near isogenic lines & Doubled haploid lines \\
\hline Herbicide & Pre-drilling & Glyphosate $1.8 \mathrm{~kg} / \mathrm{ha}$ & Glyphosate $1.8 \mathrm{~kg} / \mathrm{ha}$ & Glyphosate $1.8 \mathrm{~kg} / \mathrm{ha}$ & Glyphosate $1.8 \mathrm{~kg} / \mathrm{ha}$ \\
\hline Insecticide & Pre-drilling & Chlorpyriphos $0.45 \mathrm{~kg} / \mathrm{ha}$ & Chlorpyriphos $0.45 \mathrm{~kg} / \mathrm{ha}$ & Chlorpyriphos $0.45 \mathrm{~kg} / \mathrm{ha}$ & Chlorpyriphos $0.45 \mathrm{~kg} / \mathrm{ha}$ \\
\hline Herbicide & 19 & - & $\begin{array}{l}\text { Diflufenican } 100 \mathrm{~g} / \mathrm{ha}+ \\
\text { Isoproturon } 1 \mathrm{~kg} / \mathrm{ha}\end{array}$ & $\begin{array}{l}\text { Diflufenican } 100 \mathrm{~g} / \mathrm{ha}+ \\
\text { Isoproturon } 1 \mathrm{~kg} / \mathrm{ha}\end{array}$ & $\begin{array}{c}\text { Pendimethalin } 1.2 \mathrm{~kg} / \mathrm{ha}+ \\
\text { (Carfentrazone-ethyl } 20 \mathrm{~g} / \mathrm{ha}+ \\
\text { Flupysulfuron-methyl } 10 \mathrm{~g} / \mathrm{ha} \text { ) }\end{array}$ \\
\hline Nutrition & $30-31$ & $100 \mathrm{~kg} \mathrm{~N} / \mathrm{ha}+40 \mathrm{~kg} \mathrm{~S} / \mathrm{ha}$ & $100 \mathrm{~kg} \mathrm{~N} / \mathrm{ha}+40 \mathrm{~kg} \mathrm{~S} / \mathrm{ha}$ & $100 \mathrm{~kg} \mathrm{~N} / \mathrm{ha}+40 \mathrm{~kg} \mathrm{~S} / \mathrm{ha}$ & $100 \mathrm{~kg} \mathrm{~N} / \mathrm{ha}+40 \mathrm{~kg} \mathrm{~S} / \mathrm{ha}$ \\
\hline Fungicide & $30-31$ & $\begin{array}{c}\text { Epoxiconazole } 125 \mathrm{~g} / \mathrm{ha}+ \\
\text { Quinoxyfen } 150 \mathrm{~g} / \mathrm{ha}\end{array}$ & $\begin{array}{l}\text { Epoxiconazole } 125 \mathrm{~g} / \mathrm{ha}+ \\
\text { Quinoxyfen } 150 \mathrm{~g} / \mathrm{ha}\end{array}$ & $\begin{array}{c}\text { Epoxiconazole } 125 \mathrm{~g} / \mathrm{ha}+ \\
\text { Quinoxyfen } 150 \mathrm{~g} / \mathrm{ha}+ \\
\text { Chlorothalonil } 1 \mathrm{~kg} / \mathrm{ha}\end{array}$ & $\begin{array}{c}\text { Epoxiconazole } 125 \mathrm{~g} / \mathrm{ha}+ \\
\text { Quinoxyfen } 150 \mathrm{~g} / \mathrm{ha}+ \\
\text { Chlorothalonil } 1 \mathrm{~kg} / \mathrm{ha}\end{array}$ \\
\hline Herbicide & $31-32$ & $\begin{array}{l}\text { Metsulfuron-methyl 3g/ha }+ \\
\text { Thifensulfuron-methyl } 30 \mathrm{~g} / \mathrm{ha}\end{array}$ & - & Tribenuron methyl $15 \mathrm{~g} / \mathrm{ha}$ & Tribenuron methyl $15 \mathrm{~g} / \mathrm{ha}$ \\
\hline Nutrition & $34-39$ & $100 \mathrm{~kg} \mathrm{~N} / \mathrm{ha}$ & $100 \mathrm{~kg} \mathrm{~N} / \mathrm{ha}$ & $100 \mathrm{~kg} \mathrm{~N} / \mathrm{ha}$ & $100 \mathrm{~kg} \mathrm{~N} / \mathrm{ha}$ \\
\hline Fungicide & 39 & $\begin{array}{c}\text { Epoxiconazole } 125 \mathrm{~g} / \mathrm{ha}+ \\
\text { Azoxystrobin } 250 \mathrm{~g} / \mathrm{ha}^{+} \\
\text {Chlorothalonil } 1 \mathrm{~kg} / \mathrm{ha}\end{array}$ & $\begin{array}{c}\text { Epoxiconazole } 125 \mathrm{~g} / \mathrm{ha}+ \\
\text { Azoxystrobin } 250 \mathrm{~g} / \mathrm{ha}+ \\
\text { Chlorothalonil } 1 \mathrm{~kg} / \mathrm{ha}\end{array}$ & $\begin{array}{l}\text { Epoxiconazole } 125 \mathrm{~g} / \mathrm{ha}+ \\
\text { Azoxystrobin } 250 \mathrm{~g} / \mathrm{ha}\end{array}$ & $\begin{array}{l}\text { Epoxiconazole } 125 \mathrm{~g} / \mathrm{ha}+ \\
\text { Azoxystrobin } 250 \mathrm{~g} / \mathrm{ha}\end{array}$ \\
\hline Fungicide & 59 & Tebuconazole $250 \mathrm{~g} / \mathrm{ha}$ & - & Tebuconazole $250 \mathrm{~g} / \mathrm{ha}$ & Tebuconazole $250 \mathrm{~g} / \mathrm{ha}$ \\
\hline Insecticide & 61 & Deltamethrin $6.25 \mathrm{~g} / \mathrm{ha}$ & - & - & \\
\hline Herbicide & Pre-harvest & - & Glyphosate $1.44 \mathrm{~kg} / \mathrm{ha}$ & - & \\
\hline Harvested & & 02.08 .2006 & 10.08 .2007 & 03.09 .2008 & 28.08.2008 \\
\hline
\end{tabular}


Table 3 Accumulated interception of photosynthetically active radiation (PAR) and radiation use efficiency (RUE) to produce above ground biomass of near isogenic lines differing in major genes for reduced height, in three winter wheat cultivar backgrounds, grown on conventionally-managed land

\begin{tabular}{|c|c|c|c|c|c|c|}
\hline \multirow[b]{2}{*}{ Sowing date } & \multicolumn{3}{|l|}{ Mercia } & \multirow{2}{*}{$\begin{array}{l}\text { Maris } \\
\text { Widgeon } \\
3 \text { Sept. } \\
2008\end{array}$} & \multirow{2}{*}{$\begin{array}{l}\text { Maris } \\
\text { Huntsman } \\
\text { 3 Sept. } \\
2008\end{array}$} & \multirow{2}{*}{$\begin{array}{l}\text { REML } \\
\text { predicted } \\
\text { allele means }\end{array}$} \\
\hline & $\begin{array}{l}2 \text { Aug. } \\
2006\end{array}$ & $\begin{array}{l}10 \text { Aug. } \\
2007\end{array}$ & $\begin{array}{l}3 \text { Sept. } \\
2008\end{array}$ & & & \\
\hline \multicolumn{7}{|l|}{$\operatorname{PAR}\left(\mathrm{MJ} / \mathrm{m}^{2}\right)$} \\
\hline rht (tall) & 762 & 720 & 677 & 675 & 686 & 706 \\
\hline$R h t-B 1 b$ & 746 & 725 & 697 & 724 & 701 & 719 \\
\hline Rht-D1b & 722 & 687 & 679 & 674 & 704 & 693 \\
\hline$R h t 8 c+P p d-D 1 a$ & 749 & 708 & 690 & & & 714 \\
\hline Rht-B1c & 625 & 630 & 698 & 662 & 715 & 659 \\
\hline Rht-D1c & 569 & 605 & 660 & & & 603 \\
\hline Rht12 & 539 & 549 & 587 & & & 552 \\
\hline Rht-B1b+Rht-D1b & & & & 696 & 677 & 688 \\
\hline$R h t-D 1 b+R h t-B 1 c$ & & & & 658 & 686 & 674 \\
\hline SED & 19.7 & 35.7 & 19.6 & 19.6 & 19.6 & $\begin{array}{l}23.6^{a} \\
14.0^{b}\end{array}$ \\
\hline \multicolumn{7}{|l|}{ RUE (g/MJ) } \\
\hline rht (tall) & 1.84 & 1.38 & 2.33 & 2.43 & 1.90 & 1.79 \\
\hline Rht-B1b & 1.59 & 1.24 & 2.40 & 2.72 & 2.17 & 1.81 \\
\hline Rht-D1b & 1.67 & 1.20 & 2.23 & 2.12 & 2.36 & 1.72 \\
\hline$R h t 8 c+P p d-D 1 a$ & 1.63 & 0.87 & 2.31 & & & 1.59 \\
\hline Rht-B1c & 1.84 & 0.85 & 1.67 & 1.82 & 1.95 & 1.45 \\
\hline Rht-D1c & 1.11 & 0.49 & 1.58 & & & 1.06 \\
\hline Rht12 & 1.52 & 0.25 & 1.40 & & & 1.08 \\
\hline Rht-B1b+Rht-D1b & & & & 1.97 & 1.95 & 1.47 \\
\hline Rht-D1b+Rht-B1c & & & & 1.36 & 1.59 & 0.98 \\
\hline SED & 0.193 & 0.130 & 0.231 & 0.231 & 0.231 & $\begin{array}{l}0.173^{a} \\
0.103^{b}\end{array}$ \\
\hline$d f$ & 18 & 18 & 36 & 36 & 36 & 95 \\
\hline
\end{tabular}

${ }^{a}$ for comparing alleles only present in Maris Huntsman and Maris Widgeon (maximum SED); ${ }^{b}$ for comparing alleles present in all three backgrounds (minimum SED) 
Table 4 Harvest index and above-ground biomass at harvest maturity of near isogenic lines of cv. Mercia differing in major genes for reduced height grown on conventionally $(\mathrm{C})$ and organically $(\mathrm{O})$-managed land

\begin{tabular}{|c|c|c|c|c|c|c|c|c|c|}
\hline \multirow[t]{3}{*}{ NIL } & \multicolumn{6}{|c|}{ Harvest date } & \multirow{2}{*}{\multicolumn{2}{|c|}{$\begin{array}{l}\text { NIL } \times \text { system } \\
\text { means }\end{array}$}} & \multirow{3}{*}{$\begin{array}{l}\text { NIL } \\
\text { mean }\end{array}$} \\
\hline & \multicolumn{2}{|c|}{2 Aug. 06} & \multicolumn{2}{|c|}{10 Aug. 07} & \multicolumn{2}{|c|}{3 Sept. 08} & & & \\
\hline & $\mathrm{C}$ & $\mathrm{O}$ & $\mathrm{C}$ & $\mathrm{O}$ & $\mathrm{C}$ & $\mathrm{O}$ & $\mathrm{C}$ & $\mathrm{O}$ & \\
\hline \multicolumn{10}{|l|}{ Harvest index (\%) } \\
\hline rht (tall) & 42.9 & 37.4 & 47.6 & 37.8 & 51.3 & 40.4 & 47.1 & 38.6 & 42.8 \\
\hline Rht-B1b & 46.8 & 43.2 & 50.0 & 37.5 & 52.5 & 39.2 & 49.7 & 40.3 & 45.0 \\
\hline Rht-D1b & 46.5 & 35.4 & 49.1 & 37.9 & 52.4 & 40.6 & 49.3 & 37.9 & 43.6 \\
\hline$R h t 8 c+P p d-D 1 a$ & 46.3 & 39.2 & 46.8 & 39.0 & 52.3 & 37.9 & 48.3 & 39.0 & 43.6 \\
\hline Rht-B1c & 46.6 & 30.7 & 46.2 & 33.2 & 51.7 & 39.1 & 48.0 & 34.1 & 41.1 \\
\hline Rht-D1c & 44.4 & 28.8 & 42.1 & 23.3 & 38.6 & 31.3 & 42.2 & 27.7 & 34.9 \\
\hline Rht12 & 36.8 & 20.0 & 27.3 & 23.0 & 36.8 & 32.8 & 33.5 & 24.8 & 29.2 \\
\hline SED & 1.48 & 3.99 & 1.92 & 2.57 & 3.86 & 3.41 & $1.90^{a}$ & & 1.35 \\
\hline \multicolumn{10}{|l|}{ Biomass (t DM/ha) } \\
\hline rht (tall) & 14.0 & 12.6 & 10.0 & 8.1 & 15.7 & 7.4 & 13.3 & 9.5 & 11.4 \\
\hline$R h t-B 1 b$ & 11.9 & 10.7 & 8.8 & 8.6 & 16.7 & 6.9 & 12.4 & 8.8 & 10.6 \\
\hline Rht-D1b & 12.0 & 11.6 & 8.2 & 5.3 & 15.2 & 4.6 & 11.8 & 7.3 & 9.5 \\
\hline$R h t 8 c+P p d-D 1 a$ & 12.2 & 11.2 & 6.2 & 6.2 & 15.9 & 6.1 & 11.3 & 7.9 & 9.6 \\
\hline Rht-B1c & 11.5 & 6.0 & 5.3 & 3.6 & 11.7 & 2.6 & 9.6 & 4.1 & 6.8 \\
\hline Rht-D1c & 6.3 & 4.1 & 3.0 & 1.7 & 10.4 & 3.0 & 6.5 & 2.8 & 4.7 \\
\hline Rht12 & 8.3 & 2.1 & 1.4 & 0.9 & 8.2 & 1.2 & 6.1 & 1.3 & 3.7 \\
\hline SED & 1.39 & 1.36 & 0.76 & 0.86 & 1.69 & 1.39 & $0.78^{a}$ & & 0.55 \\
\hline$d f$ & 18 & 18 & 18 & 18 & 36 & 36 & $120^{a}$ & & 120 \\
\hline
\end{tabular}

\footnotetext{
${ }^{a}$ for the NIL $\times$ system interaction
} 
Table 5 Harvest index and above-ground biomass at harvest maturity of near isogenic lines of cv. Maris Huntsman and Maris Widgeon differing in major genes for reduced height grown on conventionally $(\mathrm{C})$ and organically $(\mathrm{O})$ managed land, harvested 3 Sept. 2008

\begin{tabular}{|c|c|c|c|c|c|c|c|}
\hline & \multicolumn{3}{|c|}{ Maris Huntsman } & \multicolumn{3}{|c|}{ Maris Widgeon } & \multirow[t]{2}{*}{ Allele mean } \\
\hline & $\mathrm{C}$ & $\mathrm{O}$ & $\begin{array}{l}\text { NIL } \\
\text { mean }\end{array}$ & $\mathrm{C}$ & $\mathrm{O}$ & $\begin{array}{l}\text { NIL } \\
\text { mean }\end{array}$ & \\
\hline \multicolumn{8}{|l|}{ Harvest index (\%) } \\
\hline$r h t($ tall $)$ & 42.0 & 42.3 & 42.1 & 38.9 & 31.9 & 35.4 & 38.8 \\
\hline$R h t-B 1 b$ & 44.6 & 42.0 & 43.3 & 45.6 & 34.7 & 40.2 & 41.7 \\
\hline Rht-D1b & 55.6 & 41.7 & 48.7 & 45.0 & 33.4 & 39.2 & 43.9 \\
\hline$R h t-B 1 b+R h t-D 1 b$ & 46.5 & 37.7 & 42.1 & 39.2 & 32.5 & 35.8 & 39.0 \\
\hline Rht-B1c & 49.3 & 38.0 & 43.6 & 38.6 & 34.6 & 36.6 & 40.1 \\
\hline Rht-D1b+Rht-B1c & 31.7 & 34.8 & 33.3 & 33.0 & 28.9 & 31.0 & 32.1 \\
\hline SED & 3.86 & 3.41 & 3.08 & 3.86 & 3.41 & 3.08 & 2.18 \\
\hline \multicolumn{8}{|l|}{ Biomass (t DM/ha) } \\
\hline rht (tall) & 16.3 & 6.5 & 11.4 & 13.1 & 6.6 & 9.9 & 10.6 \\
\hline Rht-B1b & 19.6 & 7.6 & 13.6 & 15.2 & 6.6 & 10.9 & 12.2 \\
\hline Rht-D1b & 14.2 & 8.9 & 11.5 & 16.6 & 7.2 & 11.9 & 11.7 \\
\hline Rht-B1b+Rht-D1b & 13.7 & 3.9 & 8.8 & 13.2 & 5.2 & 9.2 & 9.0 \\
\hline Rht-B1c & 12.1 & 5.3 & 8.7 & 13.9 & 5.4 & 9.7 & 9.2 \\
\hline$R h t-D 1 b+R h t-B 1 c$ & 8.9 & 2.7 & 5.8 & 11.1 & 4.0 & 7.5 & 6.7 \\
\hline SED & 1.69 & 1.39 & 1.27 & 1.69 & 1.39 & 1.27 & 0.90 \\
\hline$d f$ & 36 & 36 & 36 & 36 & 36 & 36 & 55 \\
\hline
\end{tabular}


Table 6 Means for presence and absence of markers for photoperiod insensitivity and reduced height amongst doubled haploid lines of Savannah $\times$ Renesansa harvested in 2008 for yields and partitioning of dry matter, cumulative interception of photosynthetically active radiation (PAR) and radiation use efficiency (RUE) when grown conventionally or organically. $d f>100$

\begin{tabular}{|c|c|c|c|c|c|}
\hline \multirow[t]{2}{*}{ Marker } & \multicolumn{2}{|c|}{ Conventional } & \multicolumn{2}{|l|}{ Organic } & \multirow[t]{2}{*}{ SED } \\
\hline & - & + & - & + & \\
\hline \multicolumn{6}{|c|}{ Final crop height (cm) } \\
\hline Ppd-D1a & 82.6 & 87.5 & 74.4 & 81.6 & 2.25 \\
\hline Rht-D1b & 92.6 & 77.7 & 84.1 & 71.7 & 2.18 \\
\hline Rht8c & 90.5 & 79.4 & 81.4 & 74.9 & 2.25 \\
\hline \multicolumn{6}{|c|}{ Grain yield (t DM/ha) } \\
\hline Ppd-D1a & 8.03 & 7.58 & 3.53 & 3.71 & 0.240 \\
\hline Rht-D1b & 7.40 & 8.05 & 3.73 & 3.68 & 0.222 \\
\hline Rht8c & 7.85 & 7.70 & 3.53 & 3.78 & 0.240 \\
\hline \multicolumn{6}{|c|}{ Harvest index (\%) } \\
\hline Ppd-D1a & 52.2 & 52.9 & 42.5 & 41.4 & 1.38 \\
\hline Rht-D1b & 50.5 & 54.3 & 42.0 & 42.3 & 1.30 \\
\hline Rht8c & 51.0 & 54.3 & 41.2 & 42.6 & 1.38 \\
\hline \multicolumn{6}{|c|}{ Biomass (t DM/ha) } \\
\hline Ppd-D1a & 15.4 & 14.3 & 8.2 & 9.1 & 0.54 \\
\hline Rht-D1b & 14.6 & 14.9 & 8.9 & 8.8 & 0.52 \\
\hline Rht8c & 15.4 & 14.1 & 8.6 & 9.0 & 0.54 \\
\hline \multicolumn{6}{|l|}{$\operatorname{PAR}\left(\mathrm{MJ} / \mathrm{m}^{2}\right)$} \\
\hline Ppd-D1a & 594 & 566 & & & 15.0 \\
\hline Rht-D1b & 570 & 589 & & & 12.3 \\
\hline Rht8c & 590 & 570 & & & 14.8 \\
\hline \multicolumn{6}{|l|}{ RUE (g/MJ) } \\
\hline Ppd-D1a & 2.58 & 2.53 & & & 0.071 \\
\hline Rht-D1b & 2.55 & 2.58 & & & 0.060 \\
\hline Rht8c & 2.60 & 2.51 & & & 0.071 \\
\hline
\end{tabular}




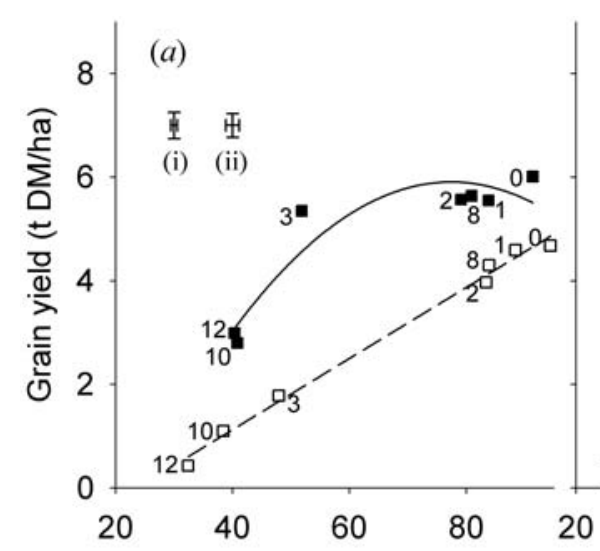

(b)

王田

(i) (ii)

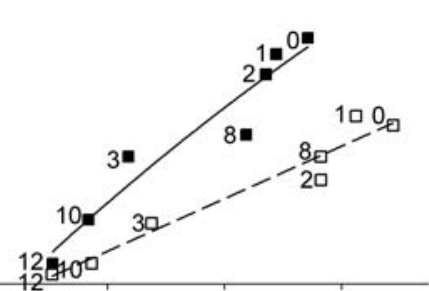

(c)

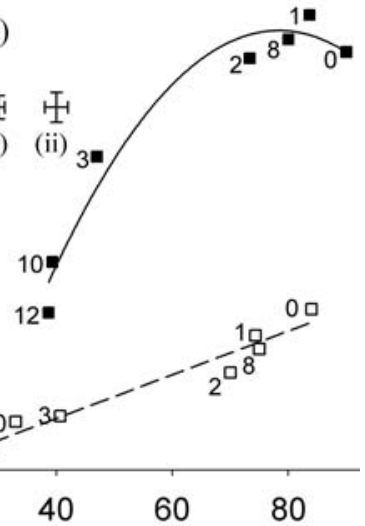

(e)

8020

$40 \quad 60$

80

开 王

(i) (ii)
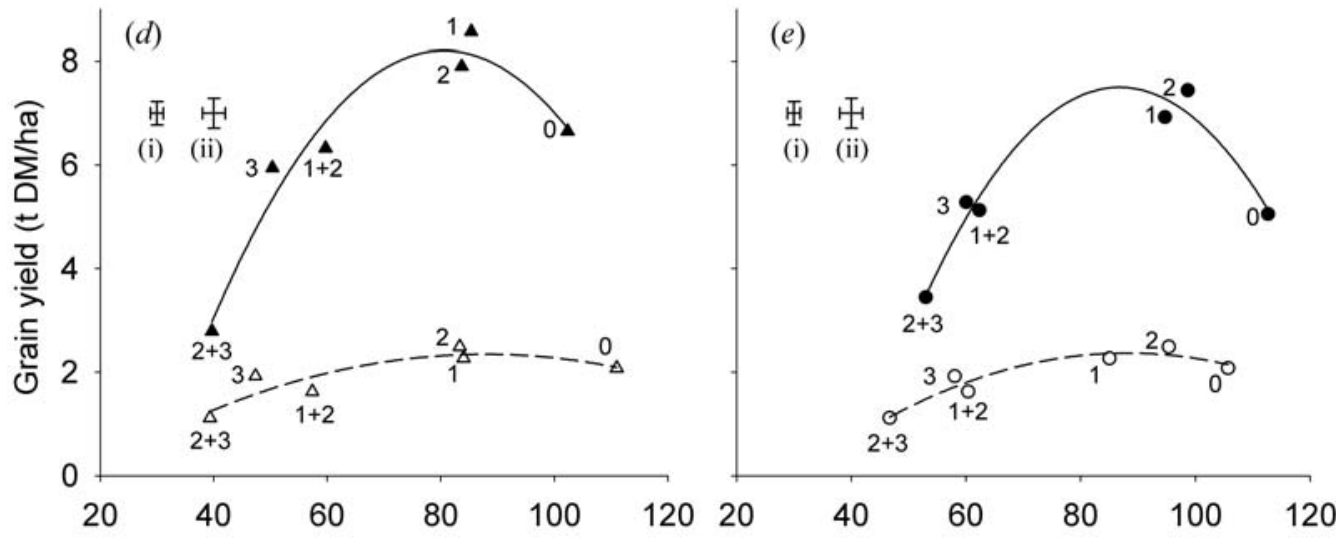

Height $(\mathrm{cm})$

Fig. 1 Relationships between height and grain yield of winter wheat NILs varying in reduced height (Rht) genes grown in a conventional (closed symbols) and an organic (open symbols) production system. $0,1,2,3,8,10,12$ correspond to rht (tall), Rht1-B1b, Rht1-D1b, Rht1-B1c, Rht8c+Ppd-D1a, Rht-D1c, Rht12 respectively in backgrounds of cvs: Mercia harvested in $a$ ) 2006, b) 2007, c) 2008; d) Maris Huntsman in 2008; and $e$ ) Maris Widgeon in 2008. Fitted lines are linear or quadratic. Error bars are SED for comparing NIL means within: i) conventional, and ii) organic systems. $d f=18,18$ and 36 for harvests in 2006, 2007 and 2008, respectively 


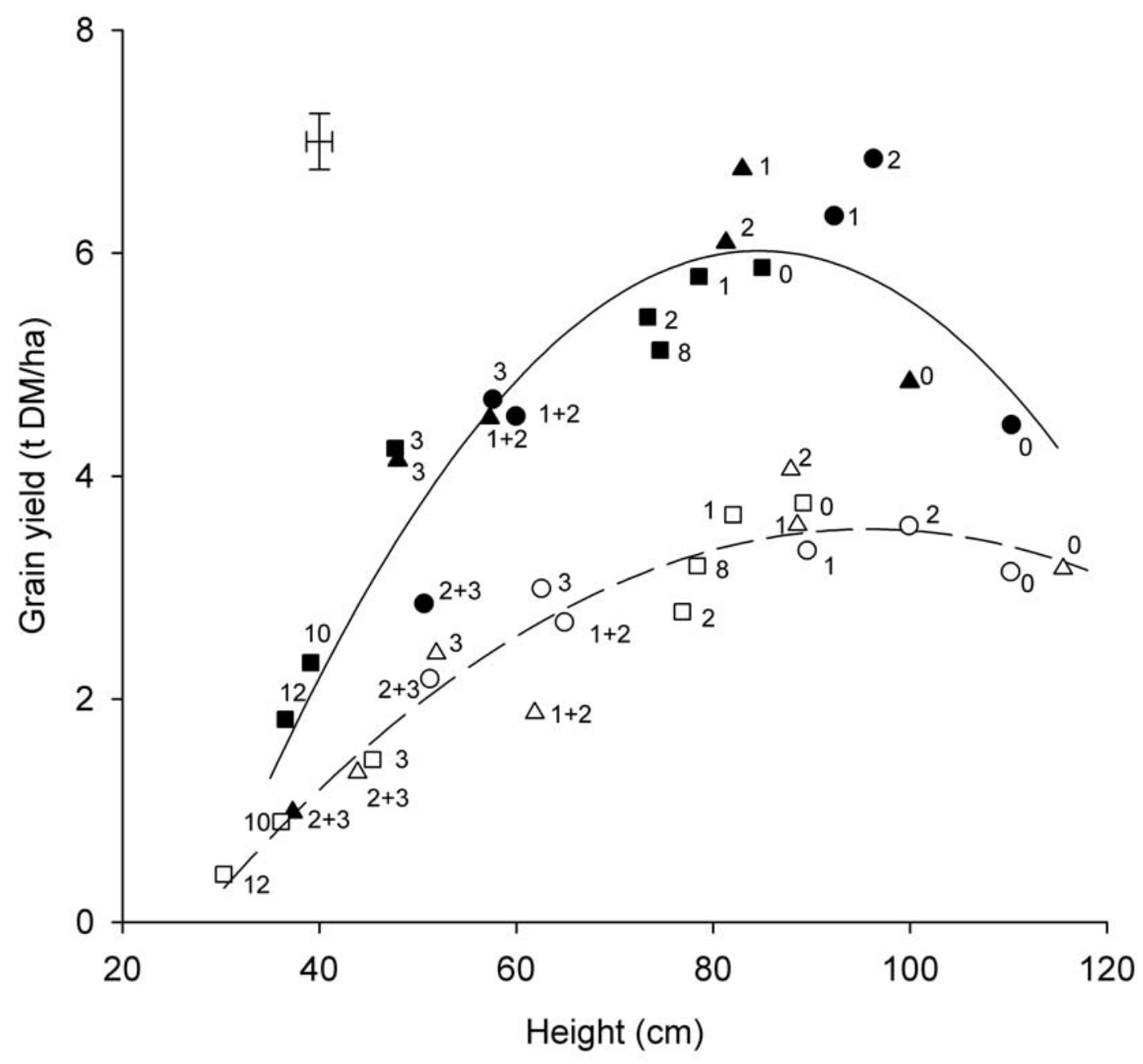

Fig. 2 Relationships between height and grain yield of winter wheat near-isogenic lines varying in reduced height (Rht) genes grown in a conventional (closed symbols) and an organic (open symbols) production system. 0, 1, 2, 3, 8, 10, 12 correspond to rht (tall), Rht1-B1b, Rht1-D1b, Rht1-B1c, Rht8c+Ppd-D1a, Rht-D1c, Rht12, respectively, in backgrounds of cvs Mercia $(\square, \boldsymbol{\bullet})$, Maris Widgeon $(\circ, \bullet)$, and Maris Huntsman $(\triangle, \mathbf{\Lambda})$. Fitted lines are quadratic. Points are predicted means from a REML analysis of genotypes compared in replicated experiments over three years, with main effects of background within system removed (see text for details). Error bars are average SEDs for comparing NIL means within systems (166 df) 


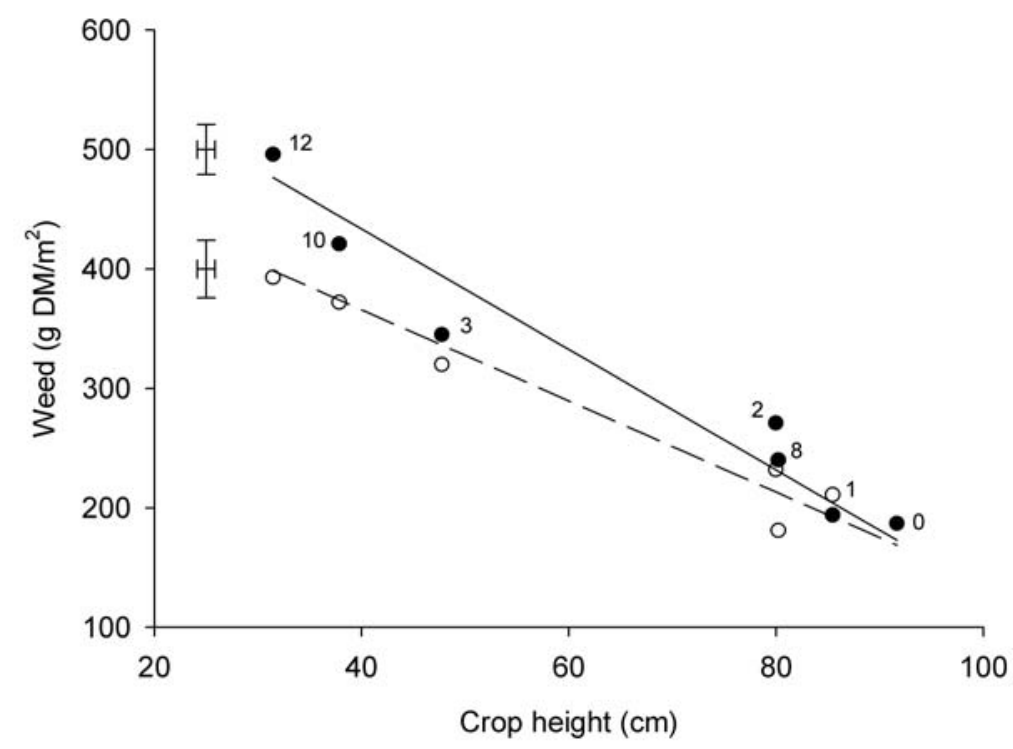

Fig. 3 Relationships with height of weed dry matter at anthesis $(\circ)$ and maturity $(\bullet)$ of winter wheat NILs of cv. Mercia varying in reduced height (Rht) genes grown in an organic production system. $0,1,2,3,8,10,12$ correspond to rht (tall), Rht1-B1b, Rht1-D1b, Rht1-B1c, Rht8c+Ppd-D1a, Rht-D1c, Rht12 respectively. Points are means from genotypes compared in replicated experiments in 2006 and 2007. Error bars are one SED for comparing NILs within systems (42 df). 

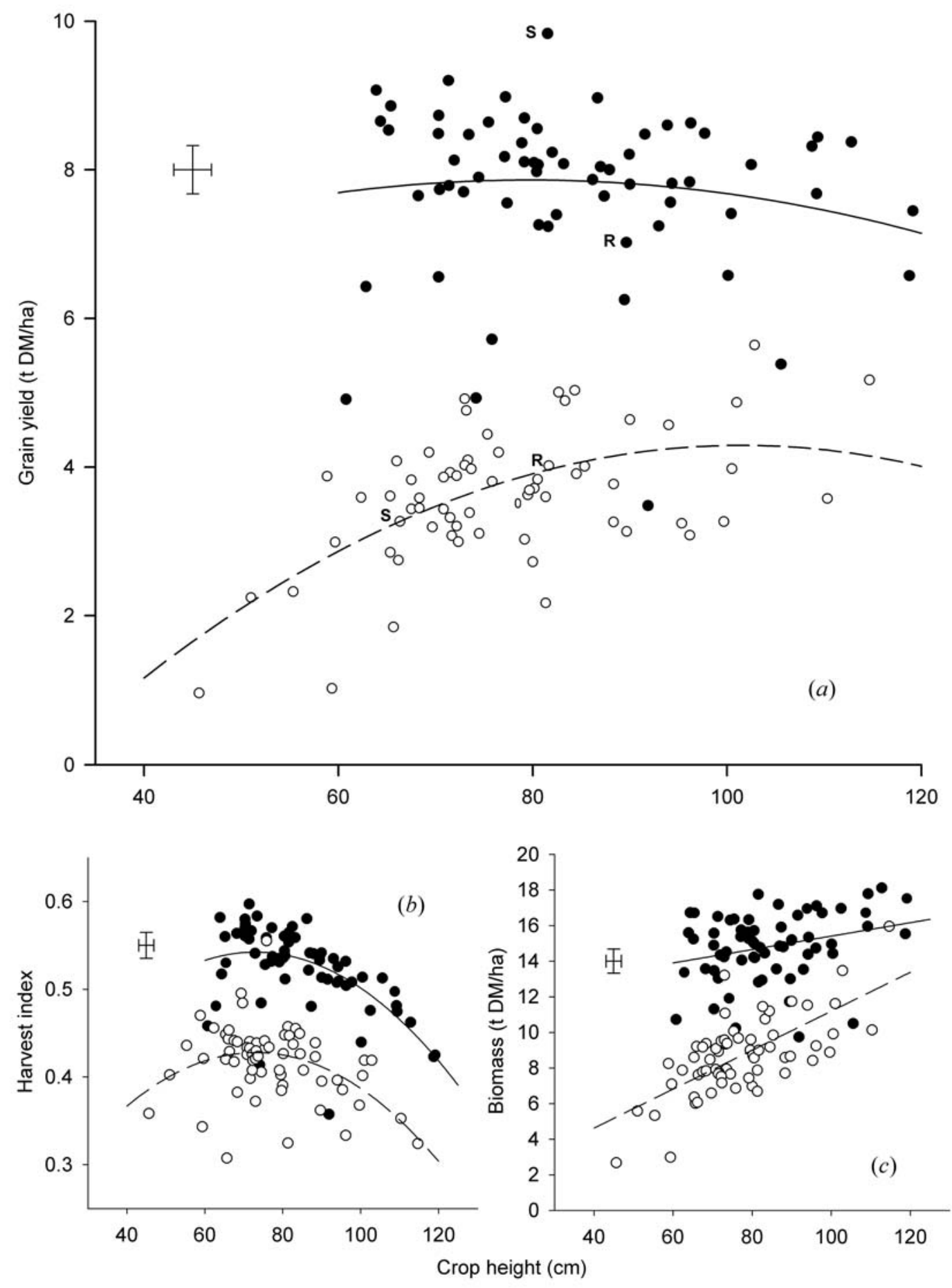

Fig. 4 Relationships between height and wheat grain yield, harvest index and above-ground crop biomass for double haploid progeny of Savannah $(\mathbf{S}) \times$ Renesansa $(\mathbf{R})$ grown in a conventional (closed symbols) and an organic (open symbols) production system. Error bars are SED for comparing DH line means within systems (125 $d f)$. 